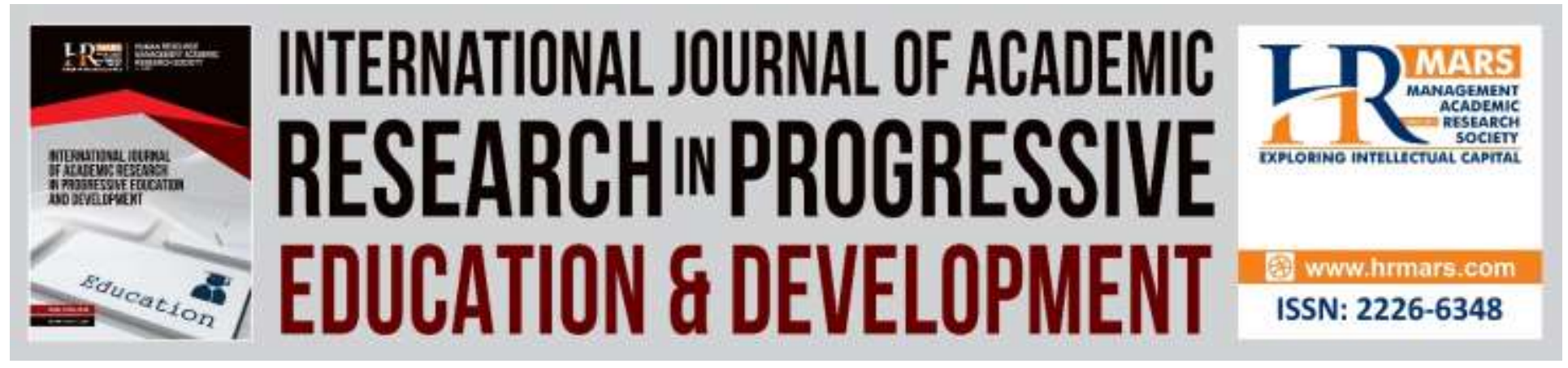

\title{
The Use of Verlan In French Film: A Sociolinguistics Study
}

\section{Najah Alia Hazman, Hazlina Abdul Halim, Mohamad Maulana Magiman}

To Link this Article: http://dx.doi.org/10.6007/IJARPED/v9-i2/7237

DOI:10.6007/IJARPED/v9-i2/7237

Received: 15 March 2020, Revised: 09 April 2020, Accepted: 11 May 2020

Published Online: 30 May 2020

In-Text Citation: (Hazman et al., 2020)

To Cite this Article: Hazman, N. A., Halim, H. A., \& Magiman, M. M. (2020). The Use of Verlan In French Film: A Sociolinguistics Study. International Journal of Academic Research in Progressive Education and Development, 9(2), 81-95.

\section{Copyright: (C) 2020 The Author(s)}

Published by Human Resource Management Academic Research Society (www.hrmars.com)

This article is published under the Creative Commons Attribution (CC BY 4.0) license. Anyone may reproduce, distribute, translate and create derivative works of this article (for both commercial and non-commercial purposes), subject to full attribution to the original publication and authors. The full terms of this license may be seen at: http://creativecommons.org/licences/by/4.0/legalcode

\section{Vol. 9(2) 2020, Pg. 81 - 95}

Full Terms \& Conditions of access and use can be found at http://hrmars.com/index.php/pages/detail/publication-ethics 


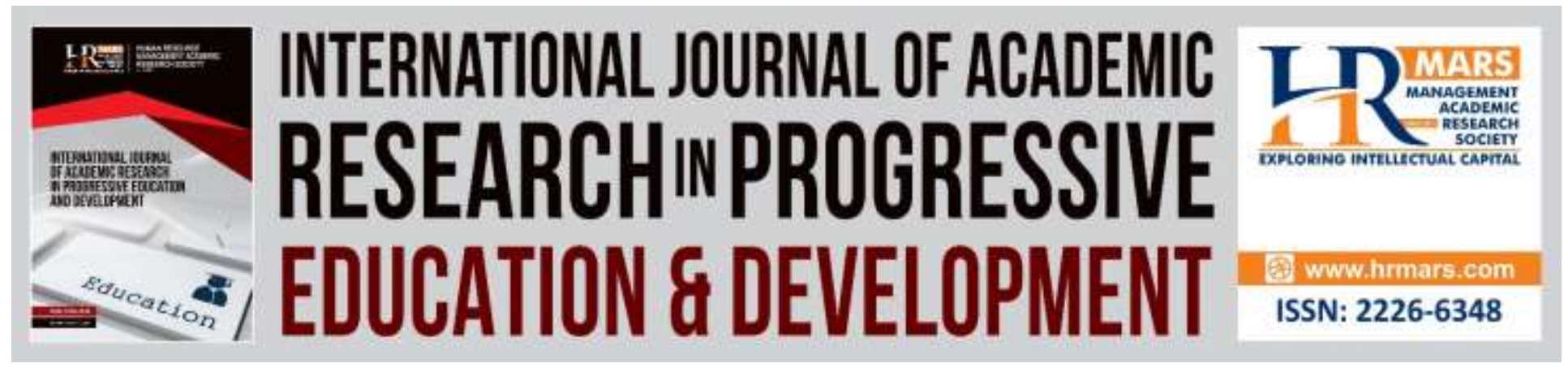

\title{
The Use of Verlan In French Film: A Sociolinguistics Study
}

\author{
Najah Alia Hazman¹, Hazlina Abdul Halim², Mohamad Maulana \\ Magiman $^{3}$ \\ 1,2Department of Foreign Languages, Faculty of Modern Languages \& Communication, \\ Universiti Putra Malaysia, 43400 UPM Serdang, Selangor, Malaysia, ${ }^{3}$ Universiti Putra Malaysia \\ Bintulu Sarawak Campus, P.O. Box 396, Nyabau Road, 97008 Bintulu, Sarawak, Malaysia. \\ Email: hazlina_ah@upm.edu.my, mdmaulana@upm.edu.my
}

\begin{abstract}
This research is carried out to study the sociolinguistics aspect of verlan in the film pattaya, directed by franck gastambide in 2016. The study will also examine the lexical aspect of the verlan used in the film. The research will combine qualitative and the simple quantitative method of data analysis. The qualitative part will be on the analysis of the corpus of the dialog which contains verlan, while the quantitative part will be elaborated to observe the lexical group of which verlan is mostly spoken. The result from this study shows that there is a strong attachment between verlan and the people in the french suburbs and the main reason of its popular use is because the efforts of its speakers to assert a sense of belongingness in the french society. Apart from that, in linguistic point of view, bi-syllables verlan is by far the most common verlan found in this film. It is also found that, lexical-wise, the adjective group of verlan is the most frequently repeated throughout the film. It is hoped from this study that the research on sociolinguistics aspect of the verlan will be expanded, in order to understand the french street language and the french youth culture.
\end{abstract}

Keywords: Verlan, Sociolinguistics, French, Pattaya.

\section{Introduction}

Verlan is a form of language long existed in France, and became widely-use by the youth from the banlieues, the French suburban "ghetto," in the 1970s. The word verlan comes from l'envers, $\left(l^{\prime}\right.$ envers $=l^{\prime}$ en + vers $=$ vers + l'en $=$ verlen $=$ verlan $)$ which in principle is a reversal of standard French word to produce a new word that acts as a method of encryption and a marker of identity. The verlan can be used on all words, from the simple ones with one syllables, two syllables or even the complicated ones with three syllables. And each time, verlan inverses the words in its own way. For example: for the words with one syllable, there are two possibilities and two different verlanisation: 
Vol. 9, No. 2, 2020, E-ISSN: $2226-6348$ @ 2020 HRMARS

1) with open syllables, the sound of the words will be inversed. for example, the word fou becomes ouf, chaud becomes auch.

2) with closed syllable, there will addition of the sound [eu]. for example, the word fête will be spelled fêteu, and verlanised as teufe, while the word bus will be spelled buseu and verlanised as seubu.

In just a few decades, verlan's popularity plummeted from suburban housing project where most africans and arabs immigrants can be found to the language of the youth in france. Today, the verlan influence has been concluded into film dialogues, advertisements, french rap songs and the current media. In fact, some of the verlanised words are also featured in the french dictionaries.

In this study, the researchers chose the film pattaya as a source of research material. the movie pattaya alone tells the story of franky and grimo who dream to leave the dullness of their neighbourhood on a trip to thailand, and more particularly the town of the title, which is a paradise for the kaïra. kaïra is a french verlan word for racaille from the suburbs which refer to lower social classes. To do this, they ask the help from karim, whom they constantly refer to as dwarf in the movie. for free tickets to thailand, they made him join a thai boxing competition for little people, even though karim does not have any boxing experience at all. They trick him into believing that he is going to mecca to perform hajj together with them. this movie has a script packed with verlanised words and that is one of the main reasons why it was selected for this study. therefore, the objectives of this study are as follows:

1. To investigate the most used lexical group of verlan in the film pattaya.

2. To examine the linguistic context of verlan in the film

3. To discuss the social context of verlan in the film.

\section{Review of Literature}

To understanding verlan's roots and functions, one must familiarize himself with the background of verlan's speakers and the cultural forms in which it is produced. As reported by lefkowitz (1991), the french ghetto areas exist outside of french major cities known as la banlieue, la cité / téci, or la zone such as seine-saint-denis and la corneuve. The residents of the suburbs live in les hlms (habitations à loyer modéré), a housing project by the government. Unfortunately, the residents are exposed to sombre economical future and they also feel isolated from the french society and culture. Bachmann \& BASIER (1984) listed four key factors that provide to the sense of segregation in the banlieues and are also favourable for the formation of special languages, which are:

1) Deindustrialization, which affects the job market to dwindle

2) Educational methods crisis

3) The disgraceful living place, such as the hlms

4) The assertion of a rebellious youth culture 
Vol. 9, No. 2, 2020, E-ISSN: $2226-6348$ @ 2020 HRMARS

Facing the above conditions, laronde (1988) proposed that young residents of the banlieue, especially the second-generation arab immigrants known as beurs (verlan for arabe), react in four different ways. some decide to accommodate into french culture. these youngsters are a small part of successful students who have the intention to fit in the society standards and culture. in the meantime, other beurs become totally against the mainstream assimilation.

The language of the suburb is an object of urban sociolinguistic study. the pioneer researcher in this field is w. Labov, who, in the year 1960's showed a high interest towards the slang of the youngsters in bronx and harlem. He considered new-yorker slangs as a variation or diversity of the official language and do not share the fears of the depletion of spoken english in the south of manhattan (labov,1979). Since the youth speakers are intensely studied by the linguists, however, the reasons of their appearance are always debatable, on whether it was about a counter-culture existing in parallel to the official culture, in the way of the speakers to claim their identity or a simple distortion of a legitimate language.

Among the studies of verlan was by peters (2006) who examined the current writing and four oeuvres between the year 1991 and 2001 to figure out which verlan words did not take after the principles of change and whether there were any guidelines behind these exemptions. The other study is by zorikacova (2010) focused on statistical analysis of the use of verlanised words in the speech of french rappers.

Many linguists believe that the counter-culture of the youth is an vital step of their socialisation and that it is connected to the variation of age and of gender. It is constructed in the contrary against the general culture, its specificity stretched on the universal base which divulges, above all, the creation of new language forms. according to most of the linguists, the identity function is more important than the communicative function (Seguin \& Teillard, 1998). in short, it can be said that "an identity form can be constituted by the production of a "we code" from a "they code", to differentiate from the speakers of "they code", for diverse reasons (Calvet, 1994).

According to Boyer (2002), the language of youth has several characteristics. firstly, it is a transmitted oral language which undergoes transformations in writing. secondly, the language is not the prerogative of the suburbs but it is the origin of terms which enrich the youth language. next, the phonetic deformation or distortion, which fundamentally diminishes to coding plays a more important function than the semantic transposition. Lastly, Boyer (2002) mentioned the youth language revives ancient slang words.

In addition, verlan speakers are different, depending on each french city. Méla (1991) expressed her observation that in general, verlan speakers are mostly males, since some girls see verlan as being too harsh and indecent. often, Lefkotwitz (1991) inferred that the best utterers of verlan is the worst students that fight against the school and social rules. the game is most commonly used in middle schools, prisons, military barracks, among the lower officers; public transportation, especially the métro; the street, especially among the school dropouts, and la cité, where drugs and criminal rates are high (Leftkotwitz,1991). 
Now when it comes to verlan function in the society, depending on the speaker, verlan serves different functions. french youth living in the banlieue who want to appear trendy, will be using verlan to identify with the oppressed, similar to that suburban wealthy american teenagers who copy the african american lingo. on the other hand, the use of verlan among the urban professionals and intellectuals is a symbol of their sensibility of the suburb's trends and problems (lefkotwitz, 1991).

\section{The Linguistic Aspect of Verlan}

Laycock (1972) invented the term "ludling", which combines the Latin ludus (game) and lingua (language). In contrast, according to Davis (1994), a ludling refers to an extensive language phenomenon with the alteration of phonologies to conceal the original meaning of the word. Bagehmil (1995) further divided ludlings into three sorts: firstly, affixing or infixing ludlings; templatic ludlings, and reversal ludlings. Verlan belongs to the category of reversal ludlings. Ludling's function is often mistaken as semantic addition to the sentence while actually it serves more as a symbol for a speaker's identity. According to Sherzer (1976), ludlings can disclose a cultural side of the speakers since the intention of reversal is camouflage, usually to show the association of a speaker's identity with a group.

Jahr (2003) mentioned about Smoi, a Norwegian language game popular among adults in Mandal, a town with small population close to the south of Norway. The term smoi derives from the Norwegian word smug, which means "narrow street" in the Mandal lingo. Jahr (2003) presents the total change principle as an act of separating the Mandal dialect word into syllables, then rearranging the sequence of syllables as one prefers, as long as it can be pronounced. Even though Smoi lacks the rule of verlan, their processes of word creation strike some similarities. If someone creates a new word in Smoi and the other users like it, the word will be passed around in the community and there is possibility of suggesting a competing form based on the original word in Mandal dialect.

\section{The Lexical Aspect of Verlan}

Verlan does not only serve as an inclusion medium, it also serves as a mask to disguise criminal activities by using jumbled words to convey the hidden message, for instance teshi from le shit, a French slang term for cannabis, and keuffor flic, a quite condescending name for a police officer (Mela, 1991). It is also common to apply verlan in the lexical fields of sex and relationships, body parts, races and violence. In her sociolinguistic study of verlan in the town of Oyonnax, France, Stewart (2010) observed that verlanised words occur most frequently in certain lexical fields, including insults, sexual vocabularies, parts of the bodies, clothing, street objects, ethnics and social groups, and kinship relations.

Lefkowitz (1989) proposed a list of the most proper lexical situations of verlan which are obscenities, subjects related to hobbies, daily life topics, issues handling with criticisms and controversial topics. Meanwhile, Paul (1985) has also listed the situations in which verlan is suitable to use, which are as follows: 
Vol. 9, No. 2, 2020, E-ISSN: 2226-6348@ 2020 HRMARS

1) Game situations with family or siblings

2) Physically or verbally violent conditions

3) Dangerous situations, including criminal activities, escaping law. In this circumstance, verlan is quick and quite useful.

4) Daily conversations where the speaker want to include sense of humour in his conversation.

\section{Research Methodology}

In this study, the researchers used simple quantitative method and qualitative method. Quantitative method involves tables and numbers while qualitative method involves text analysis, nevertheless both methods bear the same importance. In this study, textual or content analysis of the film script were used to detect the verlanised words spoken by the actors of the film and then categorise them into each of their lexical group to see which verlan is most frequently used.

The researchers started by watching the film and list down all the verlanised words occured. After that, the social context and as well as the linguistic aspect of verlan will be analysed. The lexical aspects will be observed to make sure the verlan belongs to the right category such as nouns, verbs, adjectives or prepositions. The researchers will also count the frequency of every verlan and its percentage from the total of verlan found in the film. The data will be analysed by transcribing dialogs in the film where verlan can be found. The researchers used the script transcription to analyse the data, particularly to know which verlan is often spoken in the film.

\section{Analysis and Discussion}

To analyse the use of verlan in the film, it is important to consider its sociological function and as well as its linguistic function. It is noticeable that the verlan used is representative of the spoken verlan in daily conversation. An analysis of situations where verlan is used, together with the study of linguistic aspect of verlan in the film, allow the researchers and the readers to see to what point the use of verlan in Pattaya is the representative of the real use of verlan.

\section{The Lexical Aspect of The Verlan Found in The Film}

It was found in this study, that the overall result shows that verlan from the adjective word class is the most frequently used throughout the script in the movie with $49 \%$, followed by noun verlan by $34 \%$ and the least category of verlan spoken in the movie Pattaya is verb verlan with just merely $17 \%$. The definition, word class and verlan frequency in the Pattaya film are shown in Table 1 below: 
INTERNATIONAL JOURNAL OF ACADEMIC RESEARCH IN PROGRESSIVE EDUCATION AND DEVELOPMENT

Vol. 9, No. 2, 2020, E-ISSN: 2226-6348 @ 2020 HRMARS

Table 1: Verlan and its definition in the film Pattaya

\begin{tabular}{|c|c|c|c|}
\hline Verlan & $\begin{array}{l}\text { Definition from } \\
\text { Tchatche de } \\
\text { Banlieue }\end{array}$ & Word class & $\begin{array}{l}\text { Frequency (total } \\
120 \text { times) }\end{array}$ \\
\hline Meuf & Femme/woman, p.54 & Noun & 26 \\
\hline Ouf & Fou/crazy p.58 & Adjective & 20 \\
\hline Ken & $\begin{array}{l}\text { Niquer/To make love with } \\
\text { someone p.46 }\end{array}$ & Verb & 12 \\
\hline Chelou & Louche/strange p.25 & Adjective & 10 \\
\hline Kaïra & $\begin{array}{l}\text { Racaille/ Lower class } \\
\text { society or a delinquent } \\
\text { person p. } 22\end{array}$ & Adjective & 6 \\
\hline Tej & Jeter/ To abandon p.79 & Verb & 5 \\
\hline Teub & $\begin{array}{l}\text { Bite/ Male's genital } \\
\text { p.80 }\end{array}$ & Noun & 5 \\
\hline Relou & Lourd/ Annoying p.70 & Adjective & 5 \\
\hline Se-gro & Grosse/ big p.73 & Adjective & 4 \\
\hline Renoi & Noir / black p.67 & Noun & 3 \\
\hline Teubé & Bête/Idiot p.80 & Adjective & 3 \\
\hline Vénère & $\begin{array}{l}\text { Énervé/to admire } \\
\text { p.85 }\end{array}$ & Adjective & 2 \\
\hline Queurblo & $\begin{array}{l}\text { Bloqueur / Drug } \\
\text { dealer p.66 }\end{array}$ & Noun & 1 \\
\hline Reup & Peur/fear p.67 & Adjective & 1 \\
\hline Demer & Merde/ Horrible p.32 & Adjective & 1 \\
\hline Teshor & $\begin{array}{l}\text { Short/Short pants } \\
\text { p.80 }\end{array}$ & Noun & 1 \\
\hline Péta & Taper/ to hit p.80 & Verb & 1 \\
\hline Teuf & Fête / Party p.80 & Noun & 1 \\
\hline Pécho & Choper/to catch & Verb & 1 \\
\hline
\end{tabular}

The Social Aspect of Verlan in the Film Pattaya

The film Pattaya, directed by Franck Gastambide, a comedy actor cum director, opens with the image of French suburb or mostly knows as banlieue as the setting for the main character's place, Francky, the director himself. Thus, it enforces the origin of the verlan which has most speakers from the suburb part of France compared to big city like Paris. According to Lefkowitz $(1989,1991)$, those who live in the banlieue often reside in huge public housing projects, les HLMs (habitations à loyer modéré), and face dark economic prospect.

Gastambide has his own reason for choosing Pattaya, Thailand as the major background setting of this film. To quote his saying based on an interview with Allociné, 
Vol. 9, No. 2, 2020, E-ISSN: 2226-6348 C 2020 HRMARS

" Franck Gastambide explique par ailleurs que la station est très prisée par les jeunes des banlieues françaises pour son faible coût de la vie et son climat bien sûr, mais aussi parce que dans cet endroit "ils ne se font pas refouler des boîtes de nuit..." »

Translation: Franck Gastambide explains that the resort is very popular with young people in the French suburbs for its low cost of living and its climate of course, but also because they do not get kicked off nightclubs.

In the same interview with Allociné, the actors starring in the movie, revealed that Franck Gastambide movie speaks of the phenomenon of the society since the movie is about the youth of banlieue who leaves the neighbourhood to pursue something as close as the "American dream", in Pattaya, Thailand. They also commented saying that Pattaya region in Thailand that reflected the French banlieue back in the year 1996. This shows that the director is trying to relate the banlieue or the suburb with the verlan and the kaira or in other word, the lower social class in the society.

Another example to show the relation between the lower class society and Pattaya, a suburb region in Thailand, is the scene where Krimo, the main character's best friend, was telling to Francky about his cousin Reza who opens a shop in Pattaya, by using the expression "the paradis of kaïras". The word kaïra comes from the inverse word of racaille which means person with poverty or low-class society.

Krimo : Il a ouvert une boutique là-bas. Pour se faire sa clientèle, il a fait venir des kaïras. Il avait inventé comme une sorte de slogan... "Ici, c'est le paradis des kaïras, mon frère."

All these examples demonstrating connection between banlieue or suburb area with verlan can be explained by "Speech Community Theory" proposed by Hymnes (1972), which relates common linguistic norms to a community, by illustrating that the community share mutual rules for speech interpretation. Furthermore, Stepanova (2017) stated that the stylistic functions of the suburb speakers are described as the status of the speakers, the sex of the speakers, the connection with their original countries, the exchange place (family, pair group, school) and the situation of the exchange.

In this film, Francky is portrayed as a broken-hearted guy after he has been left by his girlfriend, Laila, and to distract his mind, he does sports and frequents the gym. Krimo, his best friend, on the other hand, tries to do YouTube videos during his free time and there was once when he wanted to join a reality program, but he was not qualified for it. That is where it all started, to get out from their neighbourhood, they want to try their luck by signing up their dwarf friend, Karim to a Dwarf Boxing Championship in Pattaya for its handsome reward. As for the sex of the speakers, $95 \%$ of the cast in the film are males since overall, more males speak verlan due to the reason that some girls think verlan is more suitable or boys because it is harsh (Méla, 1991). 
Vol. 9, No. 2, 2020, E-ISSN: 2226-6348 C 2020 HRMARS

Regarding the connection with their original countries, the director of this film has put the French, the Arabic, and the black to reflect the reality of the banlieue inhabitants which comprise mostly of immigrants. For instance, 2 minutes into the movies, Francky is interrupted by a loud shout from his friends, an Arabic guy and a black guy, from outside his window. The excerpt of the dialog that contains verlan is as below:

\section{Excerpt 2 :}

Black guy : C'est vrai, ta meuf, elle t'a tej ?

Francky : C'est moi qui l'a tej !

The definition of verlan according to the dictionary Tchatche de Banlieue

Meuf : un grand classique : femme, contraction du verlan meufa. S'emploie pour les jeunes filles de tous calibres, et accessoirement pour marquer un titre de propriété. p.54.

Tej : Jeter, dans le sens larguer p.79.

In fact, it was in the year 1970s that witnessed the origin of verlan as fashion phenomenon. These were the young immigrants, mainly of Algerian descendant who created the verlan that we know today. To justify this statement, the researchers realized that the cast selection by Franck Gastambide, the Pattaya director, come mostly from Algerian and Moroccan ancestry.

Furthermore, there are a few scenes in the movie which demonstrates the influence of Arabic and Islam in the banlieue. Therefore, the researchers will show some of the scenes in the movie which contain Arabic words. As shown in Excerpt 3 below, the phrase Salam aleykoum and Inch'Allah were derived from Arabic language.

\section{Excerpt 3}

First scene: When Francky and Krimo knocked on the door of their dwarf friend Karim at 16:46, Karim appeared wearing a white cloth ready to pray and there was adhan (Islamic prayer call) playing in Karim's house.

Krimo : Salut, le nain.

Francky : Ça va?

Karim : Salam aleykoum. Vous voulez quoi ?

Francky : Il voulait juste parler d'un truc.

Second scene: When Krimo was trying to coax Karim to follow them to Pattaya at 18:50

Krimo : : Nous, on aurait voulu...Que tu viennes à ... à la Mecque.

Karim :Quoi?

Francky :Quoi?

Karim : Vous voulez vraiment qu'on parte à la Mecque tous ensemble? 
Vol. 9, No. 2, 2020, E-ISSN: 2226-6348@ 2020 HRMARS

Francky : Eh bien, Inch'Allah.

Stepanova (2017) stated that the banlieue speakers contribute to insults, derogative terms, offensive or threatening phrases which relate to 4 types: sexual insults, racist insults, insults that put the speaker's intellectual capacity in question, insults that put the speaker's moral in question. To make to it clearer, the researchers will show the verlan word in the film Pattaya and the type of insult the verlan words bear. Table 2 demonstrates the frequency for each type of insult in the film Pattaya:

Table 2: The type of insult for verlan found in Pattaya film and its frequency

\begin{tabular}{llc}
\hline Verlan & Type of insult & Frequency \\
\hline Ouf & Speaker's intelligence & 20 \\
\hline Ken & Sexual & 12 \\
\hline Teub & Sexual & 5 \\
\hline Se-gro & Speaker's moral & 4 \\
\hline
\end{tabular}

From Table 2 above, the researchers observed that the category of insult which has the highest frequency of the verlan spoken throughout the film Pattaya is the insult relating to the speaker's intelligence with the verlan ouf, being uttered 20 times in the film. Ouf originates from the French adjective fou, to describe the word "crazy" in English.

The second most popular category of insult in this film is sexual insult with 20 times of being mentioned in the script. This researchers found that this result is not unsurprising, since the film's title is self-explained. Pattaya is a sultry region in Thailand, filled with night clubs and famous for the women who work as sex workers. Thus, the characters in the film are bound to use the verlan ken, which is the inversion of the word niquer which means to make love to someone. The word ken is being used a lot of times especially in the scene where Reza, Krimo and Francky were out in the street of Pattaya, filled with night clubs and sex workers and Krimo blurted out J'ai envie de ken! upon seeing the beautiful Thai women. Furthermore, the third highest insult category is still sexual insult but with a stark difference of number of frequency whereby teub, which refers to the male genital area, is only repeated 5 times in the film, compared to ken, which lies in the same category but has a more frequent repetition of 12 times. This is rational to the opinion of Lefkotwitz (1991) who cites the factor of crudeness in verlan, which permits the use of vulgar language with the intention of softening the vulgarity by disguising it.

\section{The Linguistic Aspect of Verlan in the film Pattaya}

The popularity of verlan is explained by its diverse function. For the people of the banlieue, especially the youth, the verlan represents a way to express their feeling of non-belongingness and it has become a popular language among all the youth in France. For them, verlan represents more of a game rather than a culture. Even if the verlan stays a language of youth, nothing can ignore its existence. 
Vol. 9, No. 2, 2020, E-ISSN: 2226-6348 @ 2020 HRMARS

To understand the use of verlan in the film, it is convenient to study its construction and his placing in a conversation. The question is to know what is the role of verlan in the replies of a conversation. Therefore, the researchers decided to do a study concerning the place of verlan in the conversations and the replies in the film and the place of these words within the sentence.

To respond to this question, it is necessary to create a table of the replies and the place of replies in every reply. The table is then divided in 2 replies with the name of actors who pronounce it. The table also indicates if the first reply represents the beginning of a conversation, noted in the table as BC, or if the reply is a sentence in the middle of a conversation which contains a verlan word noted in the table as MC.

Table 3: Dialog extract from the film

\begin{tabular}{|c|c|c|}
\hline Actor & First dialog & Second dialog \\
\hline Krimo BC & $\begin{array}{l}Y \text { a des mecs qui m'ont dit que la } \\
\text { meuf, tu lui payes genre un riz, un } \\
\text { habit,elle devient comme tameuf. }\end{array}$ & \\
\hline Francky MC & & $\begin{array}{l}\text { Moi, si ma meuf } \\
\text { apprend j'étais en } \\
\text { Thailande avec toi... }\end{array}$ \\
\hline Krimo BC & $\begin{array}{l}T^{\prime} \text { as plus de meuf, réveille-toi. } \\
\text { C'est fini avec Lilia. }\end{array}$ & \\
\hline Francky MC & $\begin{array}{l}\text { On lui a pas parlé depuis l'école et } \\
\text { tu veux lui proposer un combat? }\end{array}$ & T'es un ouf. \\
\hline Krimo MC & $\begin{array}{l}\text { On va avoir la peau de la teub, elle } \\
\text { va s'irriter. }\end{array}$ & \\
\hline Francky BC & Comment tu nous as fait flipper! & \\
\hline \multicolumn{3}{|l|}{ Krimo MC } \\
\hline Francky MC & $\begin{array}{l}Y \text { en a qui sont vraiment } \\
\text { chelous. Je veux dire plus } \\
\text { chelous que toi. }\end{array}$ & \\
\hline Krimo MC & C'est chelou un nain quand ça dort & \\
\hline
\end{tabular}

The researchers found that the number of verlan being spoken in the film is 120 times, and there are 96 dialogs containing at least a verlanised word. Moreover, there are 69 dialogs uttered by the main actors and 15 uttered by supporting characters who play secondary role in the film. And in the verlan dialogs used by the main actors, 30 were uttered by Francky, Krimo 36 and Karim 3.

It can be observed from Table 3 that the verlan does not appear systematically in the same place in a conversation. It just appears a few times in the dialogs in the beginning of the conversation, and most of the time it appears in the middle of the conversation. Its appearance in the sentence is no longer systematic: the verlanised words do not appear often in the beginning of the sentence and they have the tendency to be used more in the middle of the dialogs. 


\section{INTERNATIONAL JOURNAL OF ACADEMIC RESEARCH IN PROGRESSIVE EDUCATION AND}

DEVELOPMENT

Vol. 9, No. 2, 2020, E-ISSN: 2226-6348@ 2020 HRMARS

This can be explained by the fact that, the words that are regularly verlanised are the verb and the adjective, and we rarely find the nouns, the verbs and the adjectives which are often verlanised in the beginning of a phrase. Moreover, the verlan in the film is often used as emotional emphasis as it is applied frequently to highlight a word in a phrase. Most of the words from the spoken verlan in the film are the words which convey the feelings and the words that the speakers wish to emphasize in the phrase

Table 4: Verlan transformation according to the verlan found in the film Pattaya

\begin{tabular}{|c|c|c|c|c|}
\hline & & $\begin{array}{l}\text { Syllable } \\
\text { breakdown }\end{array}$ & Reversal & Truncation \\
\hline Fou & & & & Ouf \\
\hline Racaille & & & & Caillera/caille/kaïra \\
\hline Femme & & & Meu-fe & Meuf \\
\hline Jeter & & Je-te & $T e j$ & $T e j$ \\
\hline Frites & & & Te-fris & Tefris \\
\hline Bête & & & Teu-bê & teubé \\
\hline Niquer & & Ni-quer & Ké-ni & Kénn' \\
\hline Bloqueur & & & $\begin{array}{l}\text { Ké-blo/queur- } \\
\text { blo }\end{array}$ & Kéblo/queurblo \\
\hline Mater & & & Té-ma & Té-ma \\
\hline Bite & & Bi-teu & Teu-bi & Teub' \\
\hline Louche & Loucheu & & & Chelou \\
\hline Reup & & & & Peur \\
\hline Merde & & & De-mer & Demer \\
\hline Short & Shorte & Shor-te & Tes-shor & Teshor \\
\hline Lourd & & & Re-lou & Relou \\
\hline Taper & & & Per-ta & Péta \\
\hline Énervé & $\begin{array}{l}\text { Nervé (the } \\
\text { first syllable } \\
\text { omitted) }\end{array}$ & Ner-vé & & Vénère \\
\hline Noir & & & Re-noi & Renoi \\
\hline Fête & & Fê-teu & Teu-fé & Teuf' \\
\hline Grosse & & & Se-gros & Segro \\
\hline Choper & & Cho-pé & Pé-cho & Pécho \\
\hline
\end{tabular}

Taking in consideration the syllabic structure of the words which undergo transformations, the researchers can distinguish three types of verlan namely:

1) Monosyllabic verlan allows, as what being claimed by Goudaillier (2017), to "create words which that mirror the lexemes (vowel-consonant structure type) from which they are constructed (consonant-vowel type) : ouf from fou (Goudaillier, 2017). It is suffice 
INTERNATIONAL JOURNAL OF ACADEMIC RESEARCH IN PROGRESSIVE EDUCATION AND

DEVELOPMENT

Vol. 9, No. 2, 2020, E-ISSN: 2226-6348 @ 2020 HRMARS

to say that in the case of open monosyllables, the transformation of a word is a case of it undergoing an intervention, a simple consonant-vowel inversion.

2) Bi-syllabic verlan also has a mirrored mode of operation: Caillera from racaille, queurblo from bloqueur, péta from taper and pécho from chopper. Bi-syllables or di-syllables are by far the most common forms amongst verlan terms.

3) Tri-syllabic verlan happens a lot less frequent in this film, for instance: vénère from énervé. This is due to the fact that trisyllables are slightly more problematic. According to Méla (1997), very few trisyllabic forms actually exist in verlan lexicons, and these can be verlanised in a few different ways.

Meanwhile, in the case of inter-syllabic verlan, an " $\mathrm{e}$ " is added in the complex consonantal group called bourre phonetique or phonetic padding. Obsolete " $\mathrm{e}$ " facilitates the pronunciation in the standard language and serves to help the transformation of a word, the application of the verlan rules (Calvet,1994): teubé from bête, teshor from short and relou from lourd.

Nevertheless, most of the verlanised words found in the film Pattaya are the result of the syllables reversal from the French standard words, but there are those who are formed from slang words: téma, pécho, caillera/kaïra, ken, teshor.

\section{Conclusion}

Firstly, from social perspective, banlieue or the suburb area, plays a significant role in verlan and the banlieue environment is set as the major background setting in Pattaya film. Apart from that, the region Pattaya in Thailand is chosen as the main setting too because of its notoriety as the paradise of the lower class society, or in other word, is a famous ghetto area where its community speak in slang, especially verlan. In this reseacrh, is was discovered that the most famous verlan insult uttered by the cast in the film is ouf, which is verlanised from the word fou, coming from the word "crazy" in English language, which is considered as insult to the speaker's intellectual capacity (Stepanova, 2017).

Next, regarding the linguistic aspect, the researchers concluded that verlan usually appears during mid conversation instead of the beginning of conversation. Moreover, the linguistic result showed that verlan is commonly comprised of two-syllables word. Meanwhile, Pattaya's film script contain mostly verlan of the inversion from the French standard slang words.

This study adds to our understanding of how verlan is used in the community through the dialogues in Pattaya. The study is also hoped to contribute on the sociolinguistics and lexical aspects of verlan to be pursued and enriched with more in-depth through the research of other mediums and films. Quoting the words of Van Maanen (1988:120), '... we know our analysis is not finished, only over'. 
Vol. 9, No. 2, 2020, E-ISSN: 2226-6348 (c) 2020 HRMARS

\section{Recommendation for Future Research}

First and foremost, the study is limited in scope. The film that the researchers selected to be the primary medium to study the sociolinguistic aspect of verlan is veritably not enough to analyse and identifying rich characteristics of verlan. However, this study may serve as a basis for a wider scope of study, and maybe acknowledged as comparable data results that can enhance and certify a set of verlan characteristics and the purposes of inserting verlan in film scripts.

\section{References}

Altmayer, E., \& Gastambide, F. (2016). Pattaya. France : Gaumont Film Company.

Bachmann, C., \& Basier, L. (1984). Le verlan: argot d'école ou langue des Keums? Mots 8. Paris : Saint Cloud.

Bagemihl, B. (1995). The Handbook of Phonological Theory. Cambridge: Blackwell.

Boyer, H. (2002). Langue Française. Paris : Larousse.

Calvet, L. J. (1994). Les voix de la ville : Introduction à la sociolinguistique urbaine. Paris : Payot.

Davis, S. (1994). The Encyclopedia of Languages and Linguistics. Tarrytown: Pergamon Press.

Goudaillier, J-P. (2001). Comment tu tchatches: dictionnaire du français contemporain des cités. Paris: Maisonneuve et Larose.

Hymes, D. H. (1972). The ethnography of communication. New York: Holt, Rinehart \& Winston.

Jahr, E. (2003). A Norwegian adult language game, anti-language, or secret code: the Smoi of Mandaj. Philadelphia: John Benjamins Publishing Company.

Labov, W. (1979). Le Parler Ordinaire : la langue dans les ghettos noirs des États-Unis. Paris: Éditions de Minuit.

Laronde, M. (1988). La "Mouvance beure": émergence médiatique. The French Review.

Laycock, D. (1972). Towards a typology of ludlings, or playlanguages. Linguistic Communication, 6(1), 61-113.

Lefkowitz, N. (1989). Verlan: Talking backwards in French. French Review, 63(1), 312-322.

Lefkowitz, N. (1991). Talking Backwards, Looking Forwards: the French Language Game Verlan. Tübingen: Narr.

Méla, V. (1997). Verlan 2000. Langue française. 114(1), 16-34.

Méla, V. (1991). Le verlan ou le langage du miroir. Langages, 101(2), 73-94.

Paul, E. (1985). Etude des regularités morpho-syntaxiques du verlan contemporain. Unpublished master's thesis. U.E.R. de Linguistique Française. Paris 3.

Peters, N. (2006). C'est pas blesipo : Variations of Verlan. Senior Linguistics Thesis, Swarthmore College, Pennsylvania, United States. Retrieved from https://www.swarthmore.edu/sites/default/files/assets/documents/linguistics/2007_pet ers_nathaniel.pdf.

Seguin, B., \& Teillard, F. (1998). Les Céfrans parlent aux Français : chronique de la langue des cités. Paris : Éditions du Seuil.

Sherzer, J. (1976). Play Languages: Implications for (Socio)Linguistics. Philadelphia: University of Pennsylvania Press.

Stepanova, O. (2017). L'argot aux multiples visages dans le théâtre et le cinéma contemporains. Paris: L'Harmattan. 
INTERNATIONAL JOURNAL OF ACADEMIC RESEARCH IN PROGRESSIVE EDUCATION AND

DEVELOPMENT

Vol. 9, No. 2, 2020, E-ISSN: 2226-6348 @ 2020 HRMARS

Stewart, B. (2010). A sociolinguistic study of verlan in the town of Oyonnax, France. Degree thesis, University of Manchester, England, United Kingdom). Retrieved from http://languagecontact.humanities.manchester.ac.uk/McrLC/casestudies/BS/BS_Verlan.p df.

Zorikacova, M. (2010). Synchronie Dynamique de la Verlanisation dans un corpus de chansons de rap. Doctoral thesis, Masaryk University, Czech Republic. Retrieved from https://theses.cz/id/dxlc84/?furl=\%2Fid\%2Fdxlc84\%2F;lang=en 